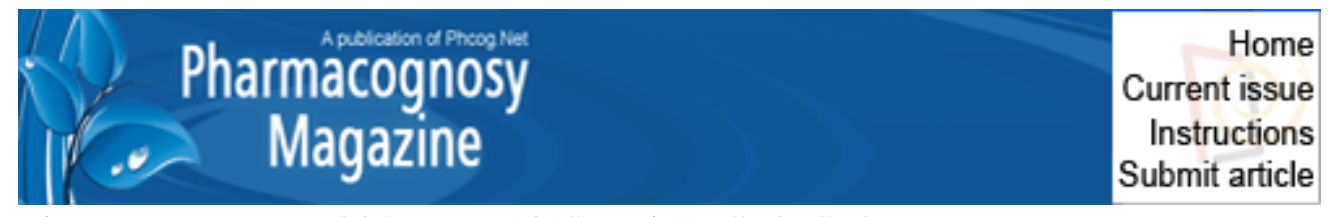

Pharmacogn Mag. 2017 Jan; 13(Suppl 1): S63-S68.

Published online 2017 Apr 7. doi: 10.4103/0973-1296.203980

PMCID: PMC5407118

\title{
In vitro Toxicity and Genotoxic Activity of Aqueous Leaf Extracts From Four Varieties of Olea europea (L)
}

$\underline{\text { Luc Verschaeve, }},{ }^{1}$ Hayet Edziri, ${ }^{2}$ Roel Anthonissen, Dalenda Boujnah, ${ }^{3}$ Fethia Skhiri, ${ }^{4}$ $\underline{\text { Hechmi Chehab }^{2}},{ }^{3}$ Mahjoub Aouni, ${ }^{2}$ and Maha Mastouri ${ }^{2}$

Scientific Institute of Public Health, Toxicology Unit, Brussels, Belgium

${ }^{1}$ University of Antwerp, Department of Biomedical Sciences, Antwerp, Belgium

${ }^{2}$ Laboratory of Transmissible Diseases and Biologically Active Substances, Faculty of Pharmacy, Monastir, Tunisia

${ }^{3}$ The Olive Tree Institute, Sousse Resort, Sousse, Tunisia

${ }^{4}$ Laboratory of Genetic Biodiversity and Valorisation of Bio Resources, Higher Institute of Biotechnology of Monastir, Monastir, Tunisia

Correspondence: Dr. Luc Verschaeve, Department of Food, Medicines and Consumers Safety, Toxicology Unit, Scientific Institute of Public health (WIV-ISP), Brussels, Belgium. E-mail: eb.psi-viw@eveahcsrev.cul

Received 2016 May 30; Revised 2016 Jul 11

Copyright : (C) 2017 Pharmacognosy Magazine

This is an open access article distributed under the terms of the Creative Commons Attribution-NonCommercial-ShareAlike 3.0 License, which allows others to remix, tweak, and build upon the work non-commercially, as long as the author is credited and the new creations are licensed under the identical terms.

\section{Abstract}

Aim:

Despite its therapeutic value almost nothing is known about potential adverse health effects of Olea europea $L$. We therefore investigated the in vitro toxicity and genotoxicity of leaf extracts of this plant.

\section{Material and Methods:}

Extracts from olive tree leaves were obtained from four different regions in Tunisia. We investigated the in vitro toxicity, genotoxicity and antigenotoxicity of their aqueous extracts using the neutral red (NR) uptake, Vitotox and alkaline comet assays.

\section{Results:}


None of the extracts were found to be toxic and none of them were genotoxic, although some doubt exists for the extract obtained at Meski (North of Tunisia). On the basis of the Vitotox test only, none of the extracts appeared to have antigenotoxic (or cogenotoxic) properties.

\section{Discussion:}

The negative genotoxicity underline the safe use of the leaves, for example, as hypoglycemic and antidiabetic preparations. Lack of antigenotoxicity may indicate that the previously reported anticancer effects do not result from protection against genotoxicity.

\section{HIGHLIGHTS}

- We investigated the in vitro toxicity and genotoxicity of aqueous extracts of olives

- The neutral Red Uptake test, Vitotox and alkaline comet assay were used

- Leaf extracts from 4 different origins were investigated

- None of them showed in vitro toxicity or genotoxicity

- The extracts also didn't have antigenotoxic properties

Abbreviation list: BaP: benzo( $\alpha$ )pyrene, EMS: ethyl methane sulfonate, LMP: low melting point, $\mathrm{NI}_{50}$ : $50 \%$ inhibition of NRU, NR: neutral red, NRU: neutral red uptake, OD: optical density, PBS: phosphate buffer saline, SDS: sodium dodecyl sulphate, S/N: signal to noise ratio, 4NQO: 4-nitroquinoline oxide

Keywords: Olea europaea L, Vitotox test, comet assay, genotoxicity, antigenotoxicity

\section{INTRODUCTION}

Olive (Olea europaea L.) is an evergreen sclerophyllous tree cultivated in the Mediterranean region since ancient times. Olive orchards have been reliable producers of food and oil for thousands of years, supporting successive civilizations in the Mediterranean area. Olea europaea (syn. Zaytoun, in Arabic) belongs to the family Oleaceae and is a small evergreen tree, from 12 to $20 \mathrm{ft}$. high, with hoary, rigid branches, and a grayish bark. It is greatly growing in developed and developing countries for its known healing effects.[1] It is for example widely used in folk medicine in the European Mediterranean area, Arabia peninsula, India, and other tropical and subtropical regions, as diuretic, hypotensive, emollient, and for urinary and bladder infections.[2] Leaves are taken orally for stomach and intestinal diseases and used as mouth cleanser.[3] Decoctions of the dried fruit and of dried leaf are taken orally for diarrhea and to treat respiratory and urinary tract infections. Leaves decoction has also hypotensive, [4] antidiabetic, [5] anti-inflammatory, [6] diuretic,[7] and anticancer[8] activities. Despite its therapeutic value, this medicinal plant was never tested for its possible adverse health effects the way our modern pharmaceutical products are. It is important to investigate not only its potential adverse effects but also its potential beneficial effects. The aim of this study is therefore to fill this gap by investigating the genotoxic activity of four varieties of Olea europea $L$ leaf extracts and to compare their activities.

\section{MATERIAL AND METHODS}

\section{Plant material}


Olea europea leaf varieties were selected from different regions in Tunisia, Chetoui (North), Meski (North), Oueslati (Center), Jarboui (Sahel). The varieties were identified by Professor Dalenda Boujnah from the olive institute of Sousse, Tunisia and voucher specimen numbers were attributed to each of the samples.

\section{Preparation of leaves aqueous extracts}

Three grams of dried material (leaves) was extracted by soaking in $100 \mathrm{~mL}$ distilled water at ambient temperature for $24 \mathrm{~h}$ in a shaker to give a concentration of $3 \%$ dry tissue. Extracts were then filtered in vacuum. First, through a Whatman \#3 disk and then, re-filtered through a nitro-cellulose paper $(\varnothing=0.45 \mu \mathrm{m})$ to reduce the risk of interference by micro-organisms.

\section{Genotoxicity test: bacterial Vitotox test}

Two Salmonella typhimurium TA104 constructs were obtained as components of the Vitotox $^{\text {TM }} 10$ Kit from GENTAUR bvba (Kampenhout, Belgium). They were grown overnight at $37^{\circ} \mathrm{C}$ (shaking) to obtain bacteria in the early logarithmic growth phase, corresponding to an approximate optical density (OD) of $0.5-0.6$ at $590 \mathrm{~nm}$. Cultures were then diluted and exposed to the test agent as described elsewhere.[9] The first construct contains a luciferase gene under control of the recN promoter, which results in light production when DNA is damaged (TA104-recN2-4 or genox strain). Light is measured with a luminometer (Modulus Microplate Multi-mode Reader, Turner Biosystems, Leiden, The Netherlands) every 5 min during $4 \mathrm{~h}$. A signal-to-noise $(\mathrm{S} / \mathrm{N})$ ratio above 1.5 indicates genotoxicity. $[9,10]$ The second strain contains the lux gene under control of a constitutive promoter so that the light production is not influenced by genotoxic compounds. This socalled TA104-pr1 strain (or Cytox strain) is used as an internal control. If light production goes down in this strain, it indicates a toxic response; if light production goes up it indicates that the test compound influences the lux gene other than via DNA damage. In this case, a "positive" response in the Genox strain probably does not reflect genotoxicity as could initially be thought. Bacteria were exposed to the extracts in different concentrations $(0.02-$ $0.1-0.5 \mathrm{mg} / \mathrm{mL}$ and $0.2-1.0-5.0 \mathrm{mg} / \mathrm{mL}$ ) in the presence and absence of a metabolizing $\mathrm{S} 9$ fraction to investigate their genotoxicity. They were also treated with the extracts together with a chemical mutagen to investigate antigenotoxicity. Therefore, extracts were tested in the same concentrations as well as in three lower concentrations (1/5 dilutions). The chemical mutagens were $0.4 \mathrm{ppm} 4$-nitroquinoline oxide (4NQO; in the absence of S9) and $800 \mathrm{ppm}$ benzo $(\alpha)$ pyrene (BaP; in the presence of S9). The mutagens were also used in the same concentration as positive controls in all tests. Bacteria and test compounds (extracts with or without mutagen) were then placed into the luminometer where light emission was measured $(4 \mathrm{~h})$. The culture medium was not changed in between. Therefore, extracts and chemical mutagens were still present in the medium when the cells were placed in the luminometer.

\section{In vitro toxicity test: the neutral red uptake test}

The NRU test[11] is based on the ability of living cells to take up and bind NR. NR is a dye which easily penetrates cell membranes via nonionic diffusion. It accumulates in the lysosomes. Xenobiotics acting on lysosomal membranes are responsible for a decreasing NR uptake. Living cells can therefore be distinguished from dead or dying cells based on their different NR uptake (NRU). We performed the NRU test according to well-known standard methods.[12] Cell suspensions of human C3A cells in Dulbecco's modified Eagle's culture medium supplemented with $10 \%$ fetal calf serum were seeded into each well of a 96 -well 
microtiter plate such that the cell density was 40,000 cells/well. Plates were incubated overnight at $37^{\circ} \mathrm{C}$ and $5 \% \mathrm{CO}_{2}$. Humidity was maintained using a water bath containing milli$\mathrm{q}$ water inside the incubator. After $24 \mathrm{~h}$ incubation, the cells were treated with dilutions of the extracts. Following another $24 \mathrm{~h}$ incubation time, cells were washed in PBS after which 200 $\mathrm{mL}$ of a $0.625 \mathrm{mg} / \mathrm{mL}$ NR-solution were added. Cells were washed $3 \mathrm{~h}$ later to remove excess of the dye. Then, $200 \mathrm{~mL}$ of a 50:1 ethanol-acetic acid solution was added to extract the dye from the cells. This was done in a microtiter plate shaker for approximately $1.5 \mathrm{~h}$ (until appearance of a homogenous purple color). Then, absorbance against a blank reference was measured at $540 \mathrm{~nm}$ using a microplate spectrophotometer. For all wells, OD values were calculated as the measured value minus the control value $\left(V_{\mathrm{c}}\right)$. Results were expressed as percentage of the OD determined from the average of the blank control culture read at $540 \mathrm{~nm}$ and set at $100 \%$. The $\mathrm{NI}_{50}(50 \%$ inhibition of NRU) was determined from the dose-response curve of the mean OD values of the different concentrations. For the positive control, a separate plate was used where cells were treated with different concentrations of sodium dodecyl sulfate (SDS; $0-0.42 \mathrm{mM}$ ), and the $\mathrm{NI}_{50}$ was determined as for the herbal extracts described above. The $\mathrm{NI}_{50}$ should be within limits that were determined from 10 independent experiments from which average $\mathrm{NI}_{50}$ values, and standard deviations were calculated (unpublished data). The calculated $\mathrm{NI}_{50}$ for the positive control in an experiment should be within 2.5 SD of these historical data for SDS. If this is not the case, the results cannot be accepted, and the test should be repeated. The reported results were all in accordance with the requirements.

\section{Genotoxicity test: comet assay}

Possible DNA breakage effects were investigated by the alkaline comet assay on human C3A hepatic cells. The test was performed according to standard methods.[13] In short, cells were grown in 24 -well plates $(1 \mathrm{~mL} / 400,000$ cells $)$. After a $24 \mathrm{~h}$ growth period, plant extracts were added in different concentrations. Concentrations were 5.0, 1.0, 0.2, and $0 \mathrm{mg} / \mathrm{mL}$. Cells were trypsinized after another $24 \mathrm{~h}$, brought to PBS and kept on ice to prevent further DNA damage. A $10 \mathrm{~mL}$ cell suspension $+300 \mathrm{~mL} 0.8 \%$ LMP agarose was brought on precoated slides (1\% NMP agarose). Slides were kept on ice for $5 \mathrm{~min}$ and then brought in lysis buffer (2.5M NaCl; 100mM EDTA; $10 \mathrm{mM}$ TRIS; $1 \mathrm{v} \%$ Triton X-100 and $10 \mathrm{v} \%$ DMSO). The $\mathrm{pH}$ was adjusted to $\mathrm{pH}=10$ with $\mathrm{NaOH}$ pellets. The slides remained overnight into the lysing solution. The next day, slides were brought into denaturation buffer $(0.3 \mathrm{M} \mathrm{NaOH}, 1 \mathrm{mM}$ EDTA in water, $\left.\mathrm{t}=17^{\circ} \mathrm{C}, \mathrm{pH}=13\right)$ in which electrophoresis $(20 \mathrm{~min}, 1.2 \mathrm{~V} / \mathrm{cm}, 300 \mathrm{~mA})$ occurred. After lysis, histones and nucleosomes were removed leaving supercoiled DNA behind. DNA damage results in broken DNA fragments and loops that will unwind and migrate in the agarose gel. A "comet-like" figure is formed that can be visualized after staining with a fluorescent dye. Slides were therefore dried, renaturated in $200 \mathrm{~mL} \mathrm{H}_{2} \mathrm{O}$ (10 min) and stained for another 10 min with $100 \mathrm{~mL}$ gel red (1:3300 stock solution). Afterward, slides were analyzed with an Axio Imager. Z2 (Zeiss) fluorescence microscope with Metacyte and Metafer 4 (version 3.8.5) software from Metasystems (Altlussheim, Germany). The percentage DNA in the comet tail was used as the measure of DNA damage. Ethyl methane sulfonate $(0.75 \mathrm{mM})$ was included as a positive control. Two slides were prepared per exposure, and a total of 100 cells (DNA comets) were measured (50 per slide). The MannWhitney U test was used to determine statistical deviations from the unexposed control cells.

\section{RESULTS AND DISCUSSION}


Most of the traditional medicinal plants have never been the subject of exhaustive (geno) toxicological tests such as is required for modern pharmaceutical compounds. On the basis of their traditional use for long periods of time, they are often assumed to be safe. But research has shown that a lot of plants with recognized beneficial properties and which are used as food ingredients or in traditional medicine can yet also be mutagenic or toxic or even carcinogenic. $[14,15,16]$ Genotoxic plants should be considered potentially unsafe and certainly require further testing before their continued use can be recommended. Plants with obvious antigenotoxic potential can, on the other hand, be considered interesting for therapeutic use and merit further in depth investigations of their pharmacological properties. This is why our research on olives (Olea europaea L.) also includes a (geno) toxicological part which is reported here. For the investigation of the potential genotoxicity/antigenotoxicity of the plant extracts, we used two indicator tests, the bacterial Vitotox test and the alkaline comet assay in human C3A cells. We chose both tests as previous investigations on a large number of medicinal plant extracts from different origin showed that a combination of both test is usually sufficient to decide upon an extract's genotoxicity profile. Therefore, the use of more time-consuming tests is apparently not imperative.[17]

The Vitotox test was at first performed in concentrations of $0.02-0.1-0.5 \mathrm{mg} / \mathrm{mL}$. This corresponds to a dose range that was found accurate in many similar experiments with plant extracts. $[18, \underline{19}]$ Then, because of lack of any effect, also higher concentrations of $0.2-1.0-5.0$ $\mathrm{mg} / \mathrm{mL}$ were studied. The concentration of $5 \mathrm{mg} / \mathrm{mL}$ corresponds with the limits of solubility. Figure 1 gives an example of the results obtained for the extract "Meski" in the absence and presence of S9. It can be seen that in cultures without addition of S9 no toxicity was found (S/N ratio in Cytox strain remains approximately "1") and that there was no genotoxicity as $\mathrm{S} / \mathrm{N}$ in the Genox strain also did not increase. In the presence of $\mathrm{S} 9$ there is a slight increase in $\mathrm{S} / \mathrm{N}$ in both the Cytox (up to $\mathrm{S} / \mathrm{N} \cong 1.2$ ) and Genox strain ( $\mathrm{S} / \mathrm{N}$ reaching levels just below 1.5) but the criteria for genotoxicity (i.e., $\mathrm{S} / \mathrm{N}>1.5$ ) were not yet fulfilled. Repeat experiments gave the same result (slight increase but at the most just below the threshold for genotoxicity). Another representation of the results is given in Figure 2 (for all extracts). It can be seen that the positive controls (4NQO and $\mathrm{BaP}$ ) always showed genotoxicity $(\mathrm{S} / \mathrm{N}>1.5$ in the Genox strain) and no toxicity ( $\mathrm{S} / \mathrm{N}>0.8$ in the Cytox strain). The tested extracts where not toxic but also not genotoxic according to the Vitotox test criteria. Borderline genotoxicity was yet found for the Meski sample in the present of S9 (as indicated before). The same holds true for the Ouslati sample (both at the maximum concentration of $5 \mathrm{mg} / \mathrm{mL}$ ) but the conclusion that none of the samples was genotoxic remains valid yet.

The comet assay was performed on human C3A cells that retain their metabolic activity. For this reason tests were only performed in the absence of S9. Investigated concentrations were the highest possible $(5 \mathrm{mg} / \mathrm{mL}$, solubility limit concentration and highest recommended dose[20]) and two further dilutions from this. All tested doses were found nontoxic in the NRU test $\left(\mathrm{NI}_{50}>90 \%\right.$; Figure 3). Figure 3 is representative for all four extracts as none of them had $\mathrm{NI}_{50}$ values lower than $90 \%$. The comet assay was therefore performed on nontoxic (but yet high) concentrations of the extracts [Figure 4]. Statistically significant deviations were found at $1 \mathrm{mg} / \mathrm{mL}$ for the Chetoui sample but this was borderline and a higher concentration did not show increased DNA damage. Extract Meski did show increased DNA damage (\% tail DNA) at the two highest concentrations. Taking the results of the Vitotox test and comet assays together we can conclude that only the Meski extract may have some genotoxic properties. However, the effect was low as can be seen when it is compared to that of well-known mutagens. Genotoxicity was, for example, much less impressive than that of 
the positive controls EMS (approximately $30 \%$ tail DNA at $0.75 \mathrm{mM}$ ), or 4NQO where concentrations of 0.075 up to $0.25 \mu \mathrm{g} / \mathrm{mL}$ showed highly significant increases of DNA damage $(P<0.001$, results not shown).

Antigenotoxicity was also investigated in the Vitotox test. Here, the same extract concentrations and three further dilutions were tested in the presence of $4 \mathrm{NQO}$ or BaP. Figure $\underline{5}$ shows the results for the concentrations $0.2-1.0-5.0 \mathrm{mg} / \mathrm{mL}$. Concentration " 0 " corresponds to 4NQO alone (without addition of an extract), concentration $0.2 \mathrm{mg} / \mathrm{mL}$ means that 4NQO was tested in conjunction with $0.2 \mathrm{mg} / \mathrm{mL}$ extract, etc. The same holds true for the samples with $\mathrm{S} 9$ where " 0 " is $\mathrm{BaP}$ alone and 0.2 is $\mathrm{BaP}+0.2 \mathrm{mg} / \mathrm{mL}$ of the extract. Figure 5 shows that the extracts do not significantly reduce (or enhance) the genotoxicity of the known mutagen and hence that the extracts apparently do not have a strong antigenotoxic (or cogenotoxic) activity. As antigenotoxicity may be concentration dependent we also investigated lower concentrations of the extracts $(1.6-8.0-40 \mu \mathrm{g} / \mathrm{mL})$. The results did not show any important deviation from the damage induced by the known mutagens (not shown). We thus conclude that the four olive extracts (Olea europaea L.) obtained from different regions in Tunisia are not genotoxic (although some doubt exist with respect to the extract collected at Meski). None has important antigenotoxic properties and also do not enhance the genotoxicity of the mutagens $4 \mathrm{NQO}$ or BaP. Lack of antigenotoxicity, may indicate that the previously reported anticancer effects[8] do not result from protection against genotoxicity. The negative genotoxicity data furthermore underline the safe use of the leaves, for example, in hypoglycemic and antidiabetic preparations.

\section{Financial support and sponsorship}

Nil.

\section{Conflicts of interest}

There are no conflicts of interest.

\section{REFERENCES}

1. Visioli F, Bellomo G, Galli C. Free radical-scavenging properties of olive oil polyphenols. Biochem Biophys Res Commun. 1998;247:60-4. [PubMed: 9636654]

2. Samova LI, Shode FO, Ramnanan P, Nadar A. Antihypertensive, antiatherosclerotic and antioxidantactivity of triterpenoids isolated from Olea europaea, subspecies Africana leaves. J Ethnopharmacol. 2003;84:299-5. [PubMed: 12648829]

3. Bellakhdar J, Claisse R, Fleurentin J, Yonos C. Repertory of standard herbal drugs in the Moroccan Pharmacopoeia. J Ethnopharmacol. 1991;35:123-43. [PubMed: 1809818]

4. De la Ribeiro R, Fiuza de Melo MM, de Barros F, Gomes C, Trolin G. Acute antihypertensive effect in conscious rats produced by some medicinal plants used in the state of Sao Paolo. J Ethnopharmacol. 1986;15:261-69. [PubMed: 3724206]

5. Alarcorn-Aguilara FJ, Roman-Ramos R, Perez-Gutierrez S, Aguilar-Contreras A, Contreras-Weber CC, Flores-Saenz JL. Study of the anti-hyperglycemic effect of plant used as antidiabetics. J Ethnopharmacol. 1998;6:101-10.

6. Pieroni A, Heimler D, Pieters L, Van Poel B, Vlietinck AJ. In vitro anticomplementary activity of flavonoids from olive (Olea europaea) leaves. Pharmazie. 1996;51:765-8.

[PubMed: 8941947] 
7. Lawrendiadis G. Contribution to the knowledge of the medicinal plants of Greece, Planta Medica. 1961;9:164-69.

8. Goldsmith CD, Vuong QV, Sadeqzadeh E, Stathopoulos CE, Roach PD, Scarlett CJ. Phytochemical properties and anti-proliferative activity of Olea europaea L. Leaf extracts against pancreatic cancer cells. Molecules. 2015;20:12992-3004. [PubMed: 26193251] 9. Verschaeve L, Van Gompel J, Regniers L, Van Parys P, van der Lelie D. VITOTOX® genotoxicity and toxicity test for the rapid screening of chemicals. Environ Mol Mutagen. 1999;33:240-8. [PubMed: 10334626]

10. Verschaeve L. High-through put bacterial mutagenicity testing: Vitotox ${ }^{\mathrm{TM}}$ assay. In: Steinberg P, editor. High through put screening methods in toxicity testing. John Wiley \& Sons; 2013. pp. 213-32.

11. Borenfreund E, Puerner JA. Toxicity determination in vitro bymorphological alterations and neutral red absorption. Toxicol Lett. 1985;24:119-24. [PubMed: 3983963]

12. Repetto G, Del Peso A, Zurita JL. Neutral red uptake assayfor the estimation of cell viability/cytotoxicity. Nat Prot. 2008;3:1125-31.

13. Olive PL, Banáth JP. The comet assay: A method to measure DNA damage in individual cells. Nat Prot. 2006;1:23-9.

14. IARC. Monographs on the evaluation of caracinogenic risks to humans. Volume 82, Some traditional Herbal Medicines, some mycotoxins, naphthalene and styrene. Lyon, France:

IARC Press; 2002. [PMCID: PMC4781602]

15. Verschaeve L, Van Staden J. Mutagenic and antimutagenic properties of South African medicinal plant extracts. J Ethnopharmacol. 2008;119:575-87. [PubMed: 18602977]

16. Ndhlala AR, Anthonissen R, Stafford GI, Finnie JF, Verschaeve L, Van Staden J. In vitro cytotoxic and mutagenic evaluation of thirteen commercial herbal mixtures sold in KwaZuluNatal, South Africa. S Afr J Bot. 2010;76:132-8.

17. Verschaeve L. Investigations of plant-derived products with the in vitro comet assay. Front. Genet. Conference Abstract: ICAW 2015-11th International Comet Assay Workshop. 2015

18. Edziri H, Mastouri M, Mahjoub A, Anthonissen R, Mertens B, Cammaerts S, et al. Toxic and mutagenic properties of extracts from Tunisian traditional medicinal plants investigated by the neutral red uptake-, VITOTOX- and alkaline comet assays. S Afr J Bot. 2011;77:70310.

19. Rashed K, Anthonissen R, Cappoen D, Verschaeve L. Evaluating potential genotoxic effects of selected Egyptian medicinal plants. Pharmacogn Comm. 2015;5:207-16.

20. Tice RR, Agurell E, Anderson D, Burlinson B, Hartmann A, Kobayashi H. Single cell gel/comet assay: guidelines for in vitro and in vivo genetic toxicology testing. Env Molec Mutagen. 2000;35:206-21. [PubMed: 10737956]

\section{Figures and Tables}




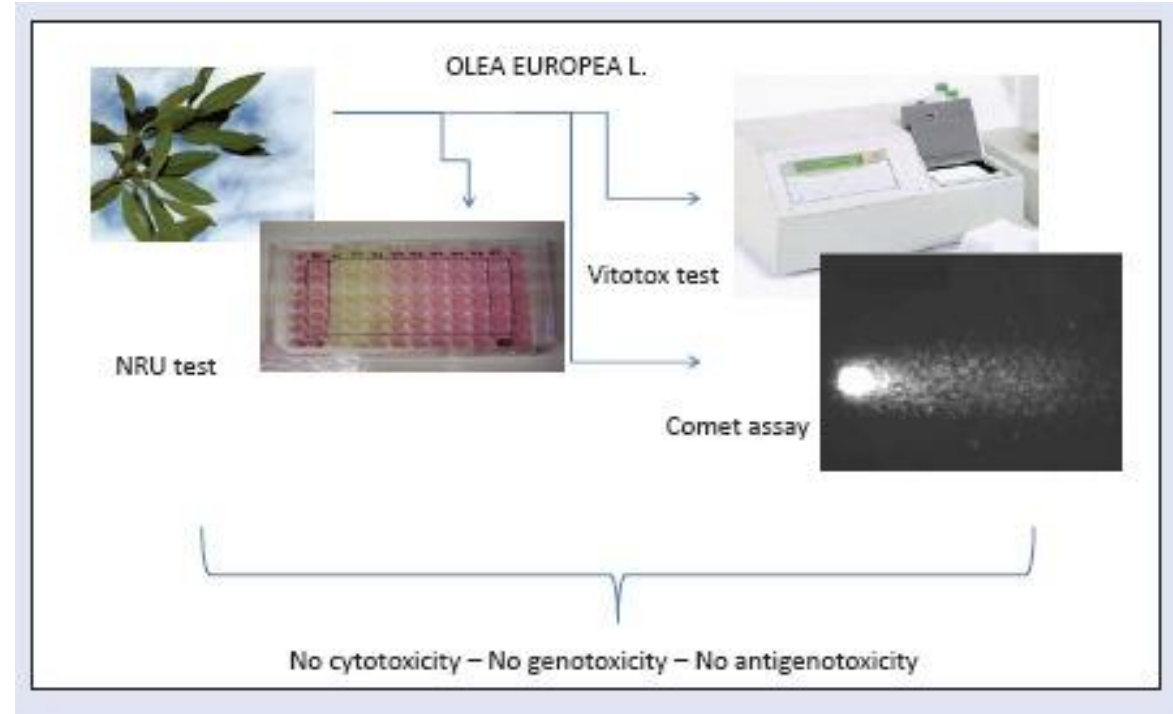

\section{Figure 1}
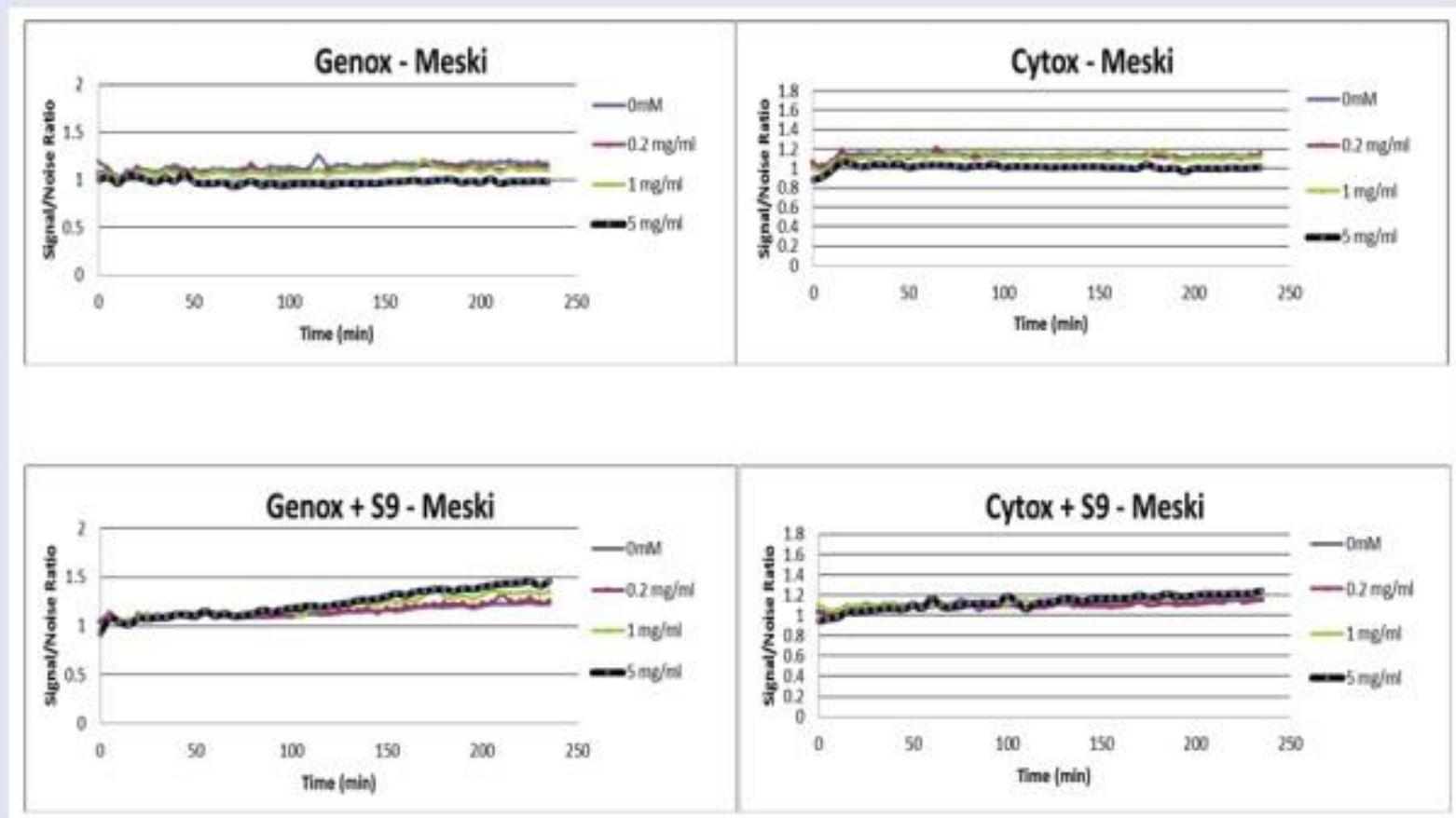

Example of Vitotox test results for one of the investigated extracts (Meski) in the absence and presence of S9.

\section{Figure 2}




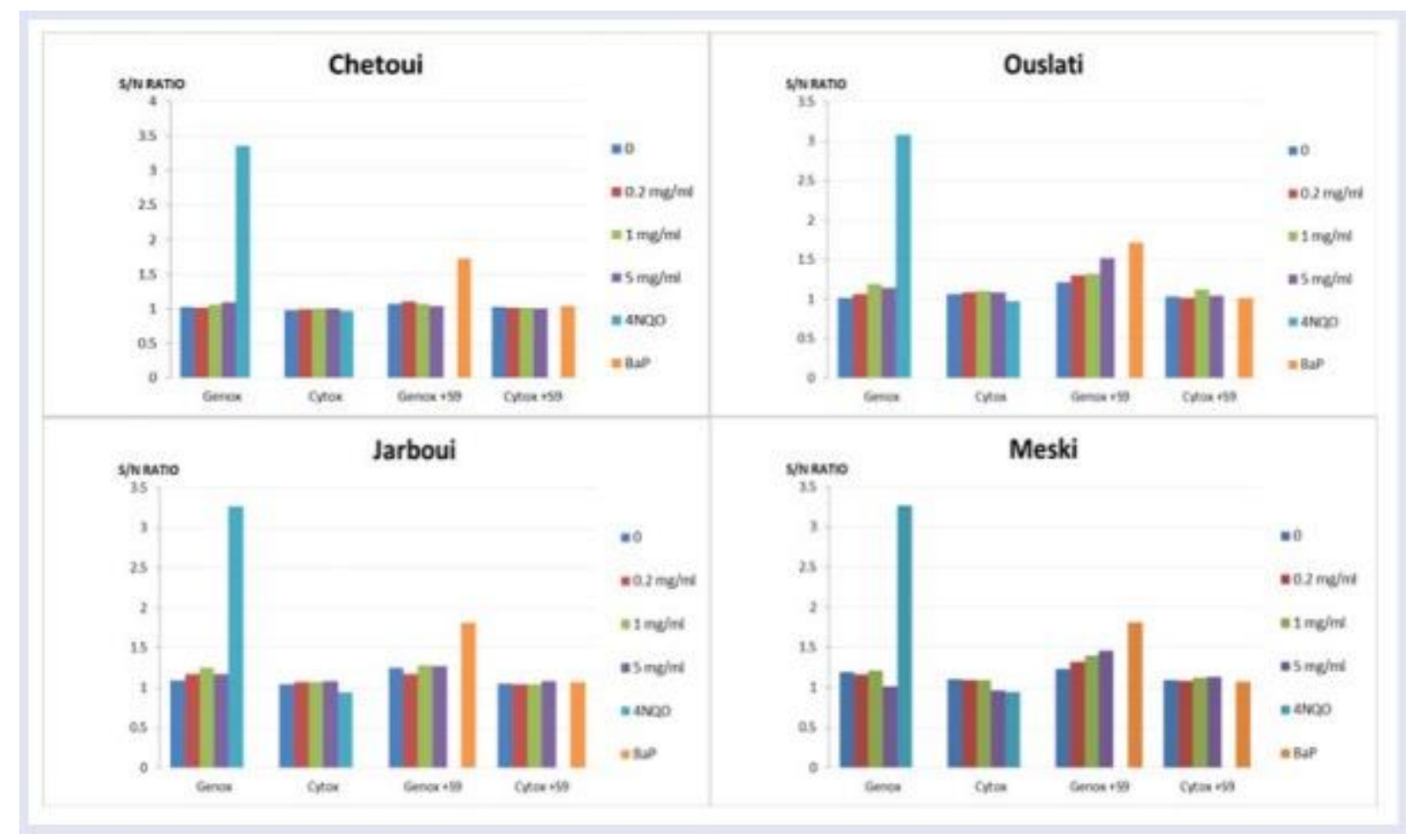

Representation of Vitotox test results for all four extracts in the presence and absence of S9.

Figure 3

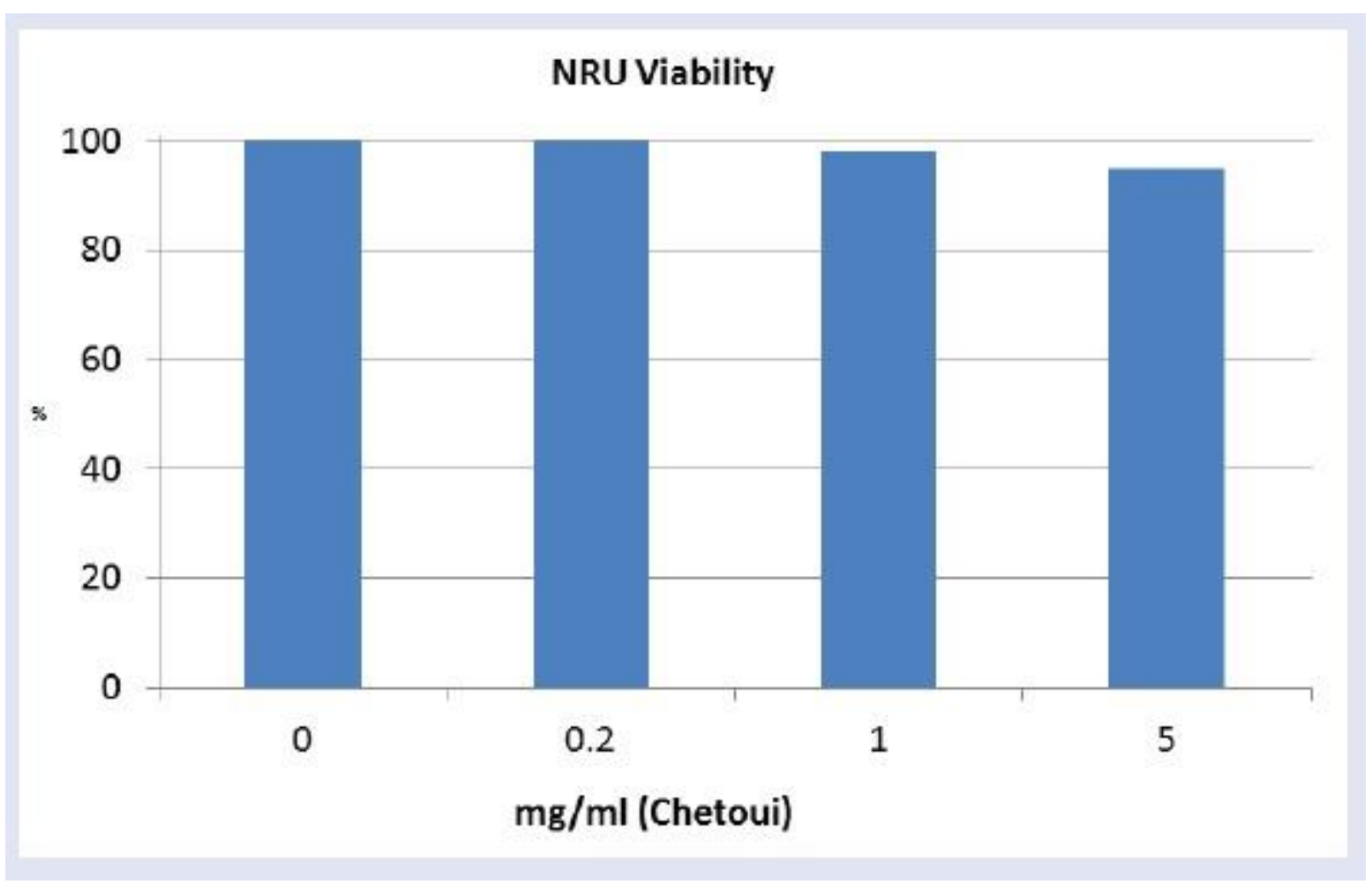

Example of NRU test results for the extract from Chetoui.

Figure 4 


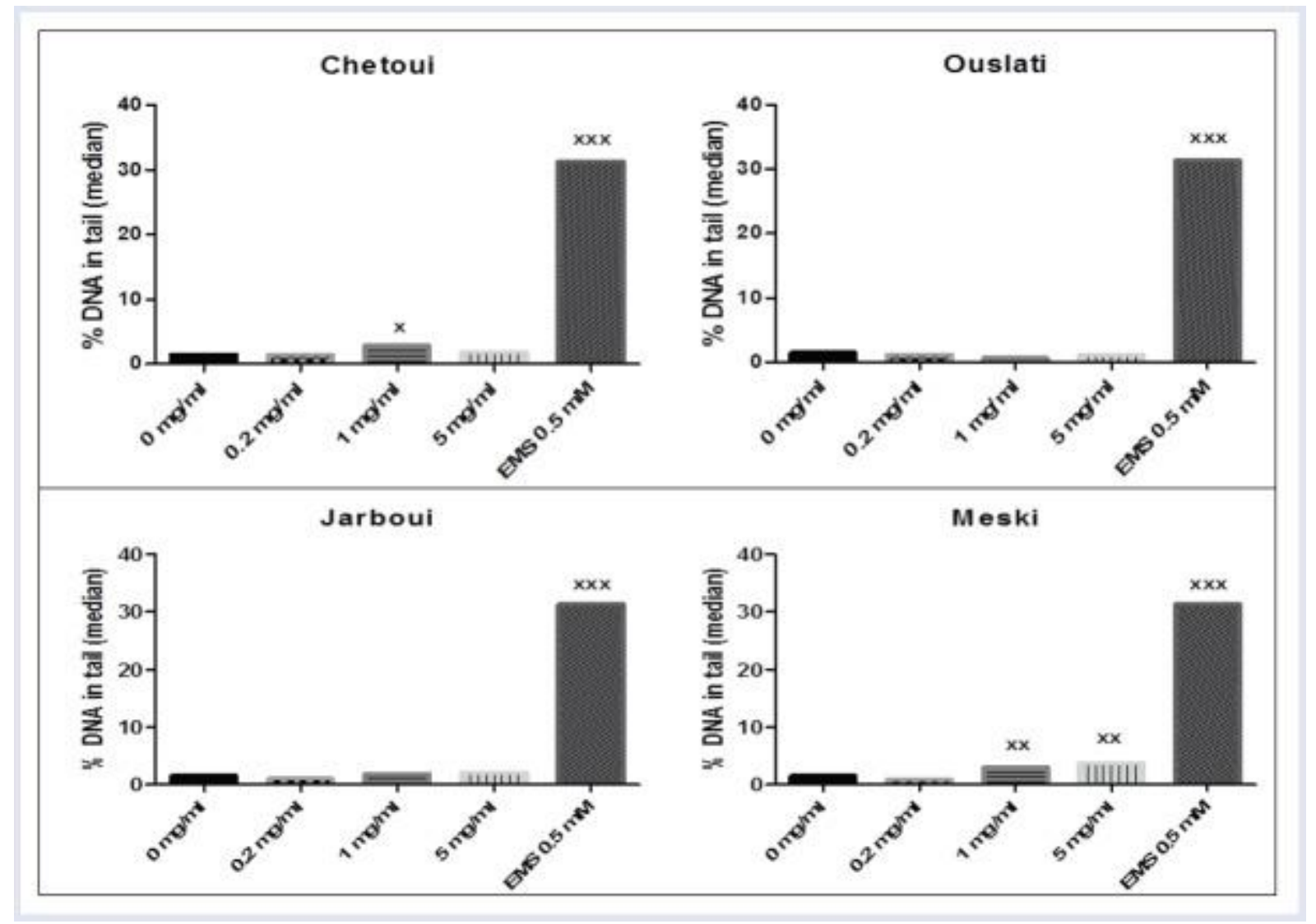

Comet test results for all four extracts. Statistical significant increases above background levels were indicated as $\mathrm{x}=P<0.05 ; \mathrm{xx}=P<0.01$, and $\mathrm{xxx}=P<0.001$.

\section{Figure 5}

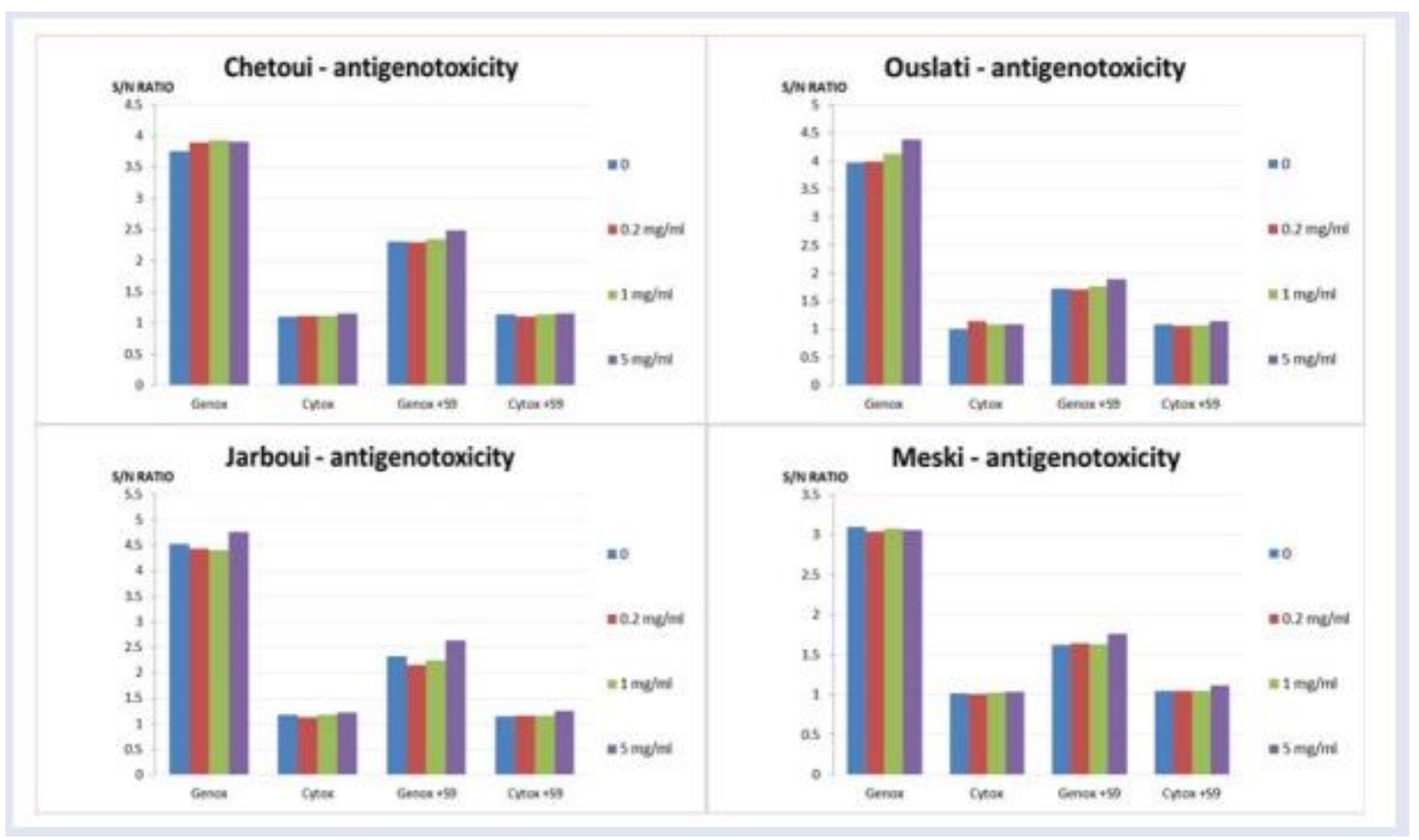


Vitotox test results on the possible antigenotoxicity of the four olive extracts.

Articles from Pharmacognosy Magazine are provided here courtesy of Medknow Publications 